

(c) Asian Fisheries Society

Published under a Creative Commons

license

E-ISSN: 2073-3720

https://doi.org/10.33997/j.afs.2021.34.3.009

\section{Effect of Mangrove Cover on Shrimp Yield in Integrated Mangrove-Shrimp Farming}

\author{
THAI THANH TRAN ${ }^{1, *}$, NGUYEN THO ${ }^{2}$, NGUYEN THI MY YEN ${ }^{1}$, NGO XUAN QUANG ${ }^{1,3}$, \\ NGUYEN THI PHUONG THAO ${ }^{1,3}$, BIJEESH KOZHIKKODAN VEETTIL ${ }^{4,5}$ \\ 'Institute of Tropical Biology, Vietnam Academy of Science and Technology, Ho Chi Minh City, Vietnam \\ ${ }^{2}$ Ho Chi Minh City Institute of Resources Geography, Vietnam Academy of Science and Technology, Ho Chi Minh City, Vietnam \\ ${ }^{3}$ Graduate University of Science and Technology, Vietnam Academy of Science and Technology, Hanoi, Vietnam \\ ${ }^{4}$ Institute of Fundamental and Applied Sciences, Duy Tan University, Ho Chi Minh City, Vietnam \\ ${ }^{5}$ Faculty of Information Technology, Duy Tan University, Da Nang, Vietnam
}

*E-mail: thanhthai.bentrect@gmail.com |Received: 26/04/2021; Accepted: 04/10/2021

\title{
Abstract
}

In recent decades, mangroves have been seriously devastated by shrimp farming development in the Vietnamese Mekong Delta. As a result, integrated mangrove-shrimp farming has emerged as a potential solution to culture shrimps and protect mangroves. The present study aims to understand whether mangrove-to-pond cover ratios influence shrimp yields in an integrated mangrove-shrimp farming system. Five integrated mangrove-shrimp ponds in the Tam Giang Commune, Nam Can District, Ca Mau Province (Southern Vietnam) were chosen for this study. The study estimated that the mangrove-to-pond cover ratios ranged from $42.00 \%$ to $72.50 \%$. The total shrimp yield per year (kg.ha-1 $\mathrm{yr}^{-1}$ ) was generally high, ranging from 76.62 to 249.09 (including 37.93 to 108.64 for the black tiger shrimp (Penaeus monodon Fabricius, 1798), and 38.69 to 140.45 for other shrimps, namely Penaeus indicus Milne Edwards, 1837, Penaeus merguiensis de Man, 1888, Metapenaeus ensis (De Haan, 1844), and Metapenaeus lysianassa (de Man, 1888)). Moreover, a strong positive correlation between the mangrove-to-pond cover ratios and the shrimp yields were observed $(r>0.71, P<0.05)$. In conclusion the mangrove-to-pond cover ratios have a direct impact on the total shrimp yield. The mangrove-to-pond cover ratios should be $50 \%$ to enhance shrimp yields in this system.

Keywords: Mekong Delta, shrimp aquaculture, sustainable development, organic shrimps, Penaeus monodon

\section{Introduction}

Mangrove forests are considered a unique habitat as they are located in coastal areas transitioning between land and sea (Fitzgerald, 2000). Mangroves are among the most productive and biologically important ecosystems of the world, in addition to their significant economic potential. They provide nutrients, habitats, nurseries, and breeding places for living organisms, surrounding estuarine and marine ecosystems (Hutchison et al., 2014; El-Regal and Ibrahim, 2014). Therefore, mangroves play a critical role in supporting the marine species that utilise mangrove habitats during part or all of their life cycles. Mangrove forests provide various services for local communities, including building materials, firewood, honey, medicinal plants, and other raw materials (Badola and Hussain, 2005; Walters et al., 2008). Mangroves could contribute significantly to climate change mitigation as they are natural barriers against hurricanes, tsunamis, cyclones, and other potentially damaging natural forces (Sandilyan and Kathiresan, 2015; Baumgartner et al., 2016).

Nowadays, mangrove forests are promising destinations for ecotourism, which serve as potential sources of income for local communities (Kusmana, 2018). However, mangroves are among the most threatened habitats in the world (Spalding et al., 2010; Giri et al., 2011). They have been affected by deforestation for villages, wood, construction materials, and growing coastal population pressures (Fitzgerald, 2000). It is estimated that over 3.6 million ha of global mangroves (20\% of total mangrove areas) have been lost since 1980 due to agriculture, aquaculture, overexploitation of resources, tourism, and urbanisation (FAO, 2007). Among degrading mangrove forests, 1.89 million ha (52\%) were cleared 
for brackish aquaculture (1.4 million ha were used for shrimp farming alone).

Most mangrove loss (1.69 million ha) occurred in Asia, where shrimp aquaculture accounts for 1.2 million ha of mangrove degradations (Valiela et al., 2001). Among shrimp producing countries, Indonesia has the highest mangrove deforestation rate $\left(52,000\right.$ ha. $\left.\mathrm{yr}^{-1}\right)$ during the 1980-2005 period (Murdiyarso et al., 2015). Several studies in Bangladesh, Brazil, China, Ecuador, India, Indonesia, Thailand, and Vietnam indicated that aquaculture resulted in $54 \%$ of the total mangrove loss between the 1980s and 1990s (Hamilton, 2013). Over 100,000 ha of mangroves were lost during the 2000-2012 period in Southeast Asia, where aquaculture was responsible for $30 \%$ of mangrove deforestation (approximately 30,000 ha)(Richards and Friess, 2016). In South Asia, 92,135 ha of mangroves was deforested during the 2000-2012 period because of shrimp farming (Giri et al., 2015). However, the loss of mangroves is rampant across the globe, especially in developing countries (López-Angarita et al., 2018).

With a long coastline of approximately 3,260 km, Vietnam is a suitable area for brackish aquaculture (Binh et al., 1997). During recent decades, the rapid expansion of shrimp aquaculture in Vietnam has resulted in its emergence as one of the largest shrimp exporters in the world (Lan, 2013). According to statistics from the Ministry of Agriculture and Rural Development of Vietnam, the country's shrimp cultivation in 2010 was estimated at over 613,000 ha (Lan, 2013). The Vietnamese Mekong Delta has the most areas and production for brackish water aquaculture (Olson and Morton, 2018). Despite significant financial benefits to the local communities, uncontrolled and unregulated practices in shrimp aquaculture have contributed to a considerable loss of mangroves and environmental degradation (Ahmed et al., 2018).

Due to the fast shrimp aquaculture expansion in Vietnam, the total mangrove area has decreased from 269,150 ha in 1980 to 157,500 ha in 2000 (FA0, 2007). Consequently, there was a need to balance between development pressures and conservation of mangrove resources. Integrated mangrove-shrimp farming system was established based on an ecofriendly approach to ease the land use conflict between mangrove conservation and shrimp farming in the Vietnamese Mekong Delta. In this method, shrimps are cultured with mangrove forests in integrated farming system, making them completely different from other production forms (Johnston et al., 2000; Baumgartner et al., 2016). Such system is popular in Ca Mau Province, Mekong Delta of Southern Vietnam ( $\mathrm{Ha}$ et al., 2012). The integrated mangroveshrimp farming system is typical for the province due to the presence of mangroves in large areas. The integrated farming system is characterised by artificially stocking black tiger shrimp and introducing wild shrimps during high tide with no feeding.
Therefore, the productivity of the integrated farming system is usually low compared with non-integrated systems (Jonell and Henriksson, 2015), and the success measures of the model depend on their productivity.

Shrimp productivities are affected by many factors, including farm management, pond size, availability of natural feed (benthos, periphyton, and plankton), water qualities (dissolved oxygen, $\mathrm{pH}$, and salinity), and weather conditions (sunlight, rainfall) (Fitzgerald, 2000; Takashima, 2000; Johnston et al., 2000). Furthermore, several factors related to mangroves can affect shrimp yields, including mangrove species, age, densities of trees (the number of trees per $\mathrm{m}^{2}$ ), and farm areas covered by mangroves (Binh et al., 1997; Bosma et al., 2014). While studies and reviews on the effects of physico-chemical variables of water and sediments on shrimp yields are increasingly common, few studies have assessed correlations between mangrove-to-pond cover ratios (MPCR) (percentage of farm areas covered by mangrove forests) and shrimp yields. In the Mekong Delta, several studies observed that high MPCR resulted in high shrimp yields (Le, 2006; Tran et al., 2013; Bosma et al., 2014). Nevertheless, so far, little attention has been given to correlations between the MPCR and shrimp yields.

By investigating an integrated mangrove-shrimp farming system in the Ca Mau Province, this study aims to measure shrimp yields and estimate the correlation between the MPCR and the yields. The findings would provide a better understanding of this successful integrated mangrove-shrimp farming system.

\section{Materials and Methods}

\section{Study area}

Tam Giang $\left(95.31 \mathrm{~km}^{2}\right)$ is a rural commune in the northeast of Nam Can District, Ca Mau Province, in the Vietnamese Mekong Delta region. This area has two distinct seasons: a rainy season (May-October) with an average seasonal rainfall of $2,100 \mathrm{~mm}$ and a dry season (November-April) with $200 \mathrm{~mm}$ rainfall. The Tam Giang Commune has dense networks of rivers and canals that interconnect as a spider's web. Furthermore, this area experiences a complex tidal regime (CMPP, 2013). This study was conducted in five integrated mangrove-shrimp ponds in the Tam Giang Commune (code P1, P2, P3, P4, and P5) (Fig. 1). The station characteristics are given in Table 1. The layout of an integrated mangrove-shrimp pond in this study is shown in Figure 2.

\section{Water management, shrimp stocking and harvest}

Both hatchery-reared postlarvae (PLs) and wild shrimps are raised in the integrated mangrove-shrimp 




Fig. 1. Map of the study area showing the five mangrove-shrimp ponds in the Tam Giang Commune (Nam Can District, Ca Mau Province).

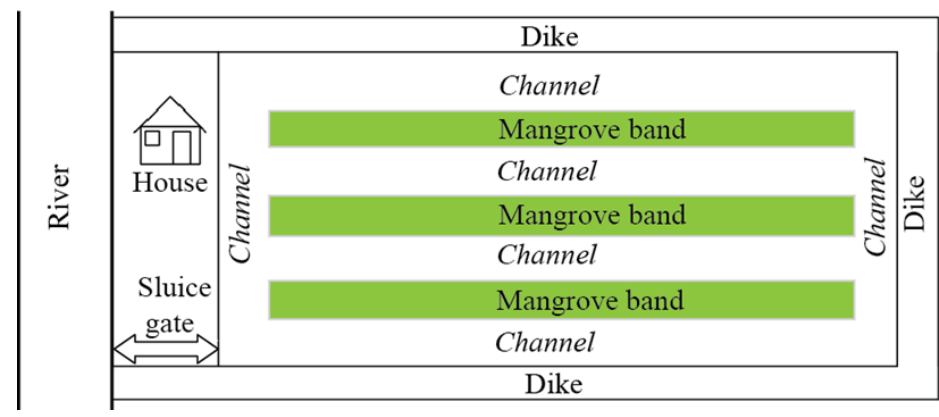

Fig. 2. The layout of integrated mangrove-shrimp ponds used for this research in Ca Mau Province, Mekong Delta, Vietnam.

Table 1. The latitude and longitude of study stations to determine shrimp yields and the mangrove-to-pond cover ratios.

\begin{tabular}{llll}
\hline Code & Hamlet & Latitude & Longitude \\
\hline P1 & Ben Dua & $8^{\circ} 46^{\prime} 59.62^{\prime \prime} \mathrm{N}$ & $105^{\circ} 05^{\prime} 23.63^{\prime \prime} \mathrm{E}$ \\
P2 & Nha Hoi & $8^{\circ} 48^{\prime} 23.04^{\prime \prime} \mathrm{N}$ & $105^{\circ} 11^{\prime} 20.79^{\prime \prime} \mathrm{E}$ \\
P3 & Bong Sung & $8^{\circ} 49^{\prime} 45.04^{\prime \prime} \mathrm{N}$ & $105^{\circ} 11^{\prime} 13.76^{\prime \prime} \mathrm{E}$ \\
P4 & Cha La & $8^{\circ} 48^{\prime} 01.57^{\prime \prime} \mathrm{N}$ & $105^{\circ} 08^{\prime} 08.82^{\prime \prime} \mathrm{E}$ \\
P5 & Cha La & $8^{\circ} 48^{\prime} 25.02^{\prime \prime} \mathrm{N}$ & $105^{\circ} 08^{\prime} 09.62^{\prime \prime} \mathrm{E}$ \\
\hline
\end{tabular}

farming system. The stocking density of hatcheryreared PLs ranged from 3-5 postlarvae. $\mathrm{m}^{-2}$ at the start, and supplemented $50 \%$ of the original number in the following months. The PLs were released into the farms late in the afternoon when the water temperature was low. Wild shrimps were brought into the ponds through seawater intake during high tide. The sluice gate to the ponds was closed at the start of a grow-out cycle. However, farmers drained part of the pond water to harvest market-sized shrimps 4-5 months after stocking. Harvesting was done twice a month (at the end/start and the middle of the lunar months). The shrimp yield from inlet water was assumed similar between ponds and was not checked prior to filling the ponds. The most recent data of wild shrimp in the study area is not available, but it was estimated less than 1 post-larvae. $\mathrm{m}^{-3}$ of water in 1996
(Johnston et al., 2000).

\section{Determination of the shrimp yields and the mangrove-to-pond cover ratios}

Fieldwork was carried out in July 2015 in Tam Giang Commune and the research involved survey of households dedicated to shrimp farming in the integrated mangrove-shrimp farming system. Five randomly chosen households were surveyed to collect information about their pond shrimp yield and the MPCR. Structured interviews with farmers elucidated two questions: (i) What was your shrimp yield? (ii) What is the total area/mangrove coverage of your shrimp pond? 
Because black tiger shrimp has been widely farmed in this area, the study divided the shrimp yields into three catalogues: P. monodon, other shrimps, and total yield (as a sum of $P$. monodon and other shrimps). Other shrimps include $P$. indicus Milne Edwards, 1837, P. merguiensis de Man, 1888, Metapenaeus ensis (De Haan, 1844), and M. Iysianassa (de Man, 1888). Shrimp yield data were collected from each pond twice a month (4-5 days around the $1^{\text {st }}$ and the $15^{\text {th }}$ of the lunar months when shrimps were harvested) for 4 months (from April to July 2015). In total, shrimp sample data were collected seven times.

\section{Data analysis}

The shrimp yields data in different MPCR were processed in Microsoft Excel 2019 and presented as mean \pm SD. The Shapiro-Wilk test was used to check for normal distributions and Levene's test to evaluate the homogeneity of variances (both at $P>0.05$ ). The data were transformed by either square-root or log transformation if assumptions were not met. If assumptions were fulfilled, a parametric test one-way ANOVA (analysis of variance) was performed. When the assumptions were not fulfilled, the analyses were replaced by a non-parametric Kruskal-Wallis test, to identify significant differences in the shrimp yield in different MPCR. When significant differences were found $(P<0.05)$, a post hoc test (Tukey HSD or DunnBonferroni) was applied for pairwise comparisons of the shrimp yield in different MPCR. Pearson correlation coefficients were used $(P<0.05)$ to identify correlations between the shrimp yields and the different mangrove-to-pond cover ratios. All statistical tests were performed using the software Statgraphics Centurion 18 (ver. 18.1.12).

\section{Results}

\section{The mangrove-to-pond cover ratios in the five mangrove-shrimp ponds}

The total pond area ranged from 3.60 to 6.00 ha and the measured MPCR varied from 42.00 to $72.50 \%$. The MPCR increased from P1 to P5. Pond 5 had the second-lowest total area but with the highest MPCR. In contrast, P1 had a relatively high total area but with the lowest MPCR (Table 2).

\section{The shrimp yields in the different mangrove-to-pond cover ratios}

The total shrimp yield by year $\left(\mathrm{kg} \cdot \mathrm{ha}^{-1} \mathrm{yr}^{-1}\right)$ varied from 76.62 to 249.09 , including 37.93 to 108.64 for $P$. monodon, and 38.69 to 140.45 for other shrimps (Table 3). Moreover, the total shrimp yield at each sampling

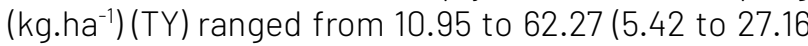
for the P. monodon (PmY), 5.53 to 35.11 for the other shrimps (OY)). Pond 5, with a MPCR of $72.50 \%$ had the highest yield, followed by pond 2 and pond 4 . The lowest yield was observed in pond 1 with a MPCR of 42 $\%$ (Fig. 3).

Table 2. The mangrove-to-pond cover ratios in the five integrated mangrove-shrimp ponds.

\begin{tabular}{lllll}
\hline Ponds & Total area (ha) & Area of water surface (ha) & Mangrove coverage (ha) & Mangrove-to-pond cover ratios (\%) \\
\hline P1 & 5.00 & 2.9 & 2.10 & 42.00 \\
P2 & 4.90 & 2.5 & 2.40 & 48.98 \\
P3 & 3.60 & 1.8 & 1.80 & 50.00 \\
P4 & 6.00 & 2.4 & 3.60 & 60.00 \\
P5 & 4.00 & 1.1 & 2.90 & 72.50 \\
\hline
\end{tabular}

Table 3. Total shrimp yield ( $\left.k g . h a^{-1} \mathrm{yr}^{-1}\right)$ in different mangrove-to-pond cover percentage ratios.

\begin{tabular}{llll}
\hline Mangrove-to-pond cover ratios & Penaeus monodon Fabricius, 1798 & Other shrimps* & Total yield \\
\hline 42 & 37.93 & 38.69 & 76.62 \\
48.98 & 90.80 & 154.40 & 245.20 \\
\hline 50 & 42.00 & 80.17 & 122.17 \\
60 & 105.83 & 115.42 & 221.25 \\
72.5 & 108.64 & 140.45 & 249.09 \\
\hline
\end{tabular}

*Other shrimps include Penaeus indicus Milne Edwards, 1837, Penaeus merguiensis de Man, 1888, Metapenaeus ensis (De Haan, 1844), and Metapenaeus Iysianassa (de Man, 1888).

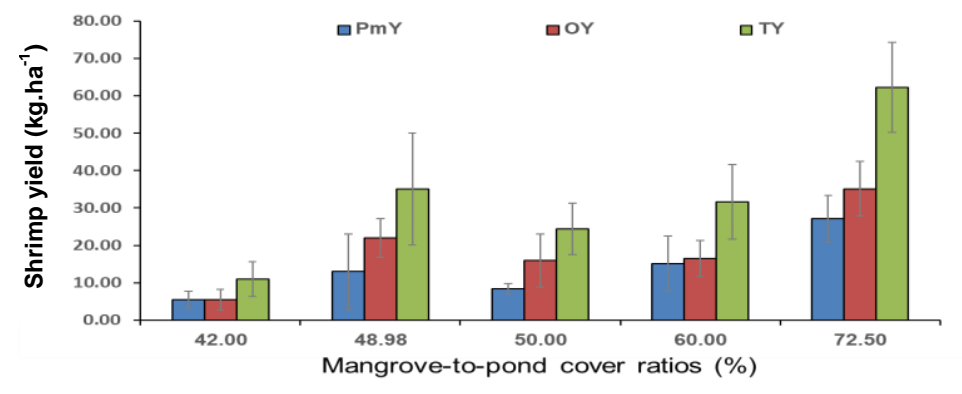

Fig. 3. Total shrimp yield at each sampling ( $\left.\mathrm{kg} \mathrm{ha}^{-1}\right)$ in the different mangrove-to-pond cover ratios. Penaeus monodon Fabricius, 1798 (PmY), other shrimps*(OY), total yield (TY). *Other shrimps include Penaeus indicus Milne Edwards, 1837, Penaeus merguiensis de Man, 1888, Metapenaeus ensis (De Haan, 1844), and Metapenaeus lysianassa (de Man, 1888). 
Because the assumptions of Levene's and ShapiroWilk tests were fulfilled, the ANOVA test was conducted to compare the $\mathrm{OY}$ and $\mathrm{TY}$ in different MPCR. Results indicated that the OY and TY were significantly different in different MPCR (both at $P<$ 0.0001). Regarding PmY, the assumptions of ShapiroWilk test were fulfilled but Levene's test did not, thus the Kruskal-Wallis test was applied. The PmY was also significantly different in different MPCR $(P=0.006<$ 0.05) (Table 4). The mean and $95 \%$ Tukey HSD and
Dunn-Bonferroni intervals for the shrimp yields in different MPCR were presented in Figure 4.

\section{Correlation between the shrimp yields and the mangrove-to-pond cover ratios}

All types of shrimp yields (PmY, OY, and TY) showed significant correlations with the MPCR (Table 5). The scatterplot matrix for these correlations is shown in Figure 5.

Table 4. Results of an ANOVA (ANO) and Kruskal-Wallis (KW) analyses of the shrimp yields in different mangrove-to-pond cover ratios.

\begin{tabular}{|c|c|c|c|c|c|c|}
\hline Variables & $n$ & $\begin{array}{l}P \text {-value } \\
\text { Shapiro-Wilk test* }\end{array}$ & $\begin{array}{l}P \text { - value } \\
\text { Levene's test** }\end{array}$ & $\begin{array}{l}\text { Types of } \\
\text { test }\end{array}$ & Df & $P$-value \\
\hline Penaeus monodon Fabricius, 1798 & 30 & 0.21 & 0.004 & KW & 4 & 0.006 \\
\hline Other shrimps*** & 30 & 0.16 & 0.46 & ANO & 4 & $<0.0001$ \\
\hline Total yield & 30 & 0.45 & 0.21 & ANO & 4 & $<0.0001$ \\
\hline
\end{tabular}

*The test should not be significant to meet the assumption of normality $(P>0.05)$. ${ }^{* *}$ The test should not be significant to meet the assumption of homogeneity of variance ( $P>0.05)$. *** Other shrimps include Penaeus indicus Milne Edwards, 1837, Penaeus merguiensis de Man, 1888, Metapenaeus ensis (De Haan, 1844), and Metapenaeus lysianassa (de Man, 1888).

Table 5. The correlation coefficients ( $r$ ) and $P$ - value of the Pearson correlation between the shrimp yields and the different mangrove-to-pond cover ratios (MPCR).

\begin{tabular}{lllll}
\hline & & Penaeus monodon Fabricius, 1798 & Other shrimps* & Total yield \\
\hline \multirow{2}{*}{ MPCR } & $r$ & 0.72 & 0.71 & 0.76 \\
& $P$ & $<0.001$ & $<0.001$ & $<0.001$ \\
\hline
\end{tabular}

$\mathrm{n}=30 .{ }^{*}$ Other shrimps include Penaeus indicus Milne Edwards, 1837, Penaeus merguiensis de Man, 1888, Metapenaeus ensis (De Haan, 1844), and Metapenaeus lysianassa (de Man, 1888).


Fig. 4. The mean and $95 \%$ Tukey HSD and Dunn-Bonferroni intervals for the Penaeus monodon Fabricius, 1798 yield (PmY)(A), other shrimp* yields (OY) (B), total yield (TY) (C). *Other shrimps include Penaeus indicus Milne Edwards, 1837, Penaeus merguiensis de Man, 1888, Metapenaeus ensis (De Haan, 1844), and Metapenaeus lysianassa (de Man, 1888).



Fig. 5. Scatterplot matrix and box-and-whisker plot for the correlation between the shrimp yields and the mangrove-to-pond cover ratios (MPCR). Penaeus monodon Fabricius, 1798 yield (PmY)(A), other shrimps* yields (OY)(B), total yield (TY)(C). *Other shrimps include Penaeus indicus Milne Edwards, 1837, Penaeus merguiensis de Man, 1888, Metapenaeus ensis (De Haan, 1844), and Metapenaeus Iysianassa (de Man, 1888). 
Table 6 shows the regression coefficients and the regression model between the shrimp yields and the MPCR. The polynomial regression of PmY, OY, TY with the MPCR was generally strong $\left(R^{2}>50 \%\right.$ of the variation explained). Figures $6 \mathrm{~A}-6 \mathrm{C}$ show a plot of a fitted model of the shrimp yields and the MPCR.

Table 6. Regression models describe the relationship between the shrimp yields and the mangrove-to-pond cover ratios (MPCR). Penaeus monodon Fabricius, 1798 yield (PmY), other shrimps* yields (OY), total yield (TY).

\begin{tabular}{|c|c|c|c|c|c|}
\hline \multirow{2}{*}{ Yields and MPCR } & \multirow{2}{*}{ Regression model } & \multicolumn{4}{|c|}{ Regression coefficients } \\
\hline & & $\mathrm{R}^{2}$ & $F$ & Df & $P$-value \\
\hline PmY and MPCR & $P m Y=-8.11+6.97^{*} \operatorname{sqrt}(M P C R)$ & 52.51 & 30.96 & 1 & $<0.001$ \\
\hline OY and MPCR & OY = sqrt(12.09 - 18.27/MPCR) & 53.30 & 31.96 & 1 & $<0.001$ \\
\hline TY and MPCR & TY $=\operatorname{sqrt}(15.53-23.18 / M P C R)$ & 59.62 & 41.35 & 1 & $<0.001$ \\
\hline
\end{tabular}

*Other shrimps include Penaeus indicus Milne Edwards, 1837, Penaeus merguiensis de Man, 1888, Metapenaeus ensis (De Haan, 1844), and Metapenaeus lysianassa (de Man, 1888).


Fig. 6. The fitted model of the shrimp yields and the mangrove-to-pond cover ratios (MPCR). Penaeus monodon Fabricius, 1798 yield (PmY) (A), other shrimps* yields (OY) (B), total yield (TY) (C). *Other shrimps include Penaeus indicus Milne Edwards, 1837, Penaeus merguiensis de Man, 1888, Metapenaeus ensis (De Haan, 1844), and Metapenaeus lysianassa (de Man, 1888).

\section{Discussion}

\section{Shrimp yields}

The total shrimp yield ranged from 76.62 to 249.09 $\mathrm{kg} \cdot \mathrm{ha}^{-1} \mathrm{yr}^{-1}$, similar to those in Enterprises 184 and Tam Giang III in Nam Can (Johnston et al., 2000) and Ngoc Hien District of Ca Mau Province (Ha 2012), and in many parts of Indonesia (Fitzgerald, 2000) (Table 7). However, it was lower and showed minor deviations than those in Ca Mau (Binh et al. 1997) and Ben Tre Province (Bosma et al. 2014). The total shrimp yield in this study was somewhat lower than similar system in Indonesia (Fitzgerald, 2000) because shrimps rely completely on natural food whereas supplementary feeding (trash fish) and fertilisers are provided in most of the integrated mangrove-shrimp ponds in Southeast Asia (Johnston et al., 2000). Hence, a direct comparison of yields with this study in Ca Mau is difficult. The marked variation in shrimp production between farms reflected the lack of experience in culture techniques, farm management, fluctuating water quality and availability of natural feed (Fitzgerald, 2000; Takashima, 2000; Johnston et al., 2000).

\section{The relationship between the mangrove-to-pond cover ratios and the shrimp yields}

Mangroves contribute a large amount of organic matter to the integrated mangrove-shrimp ponds (Fitzgerald, 2000). Productivities or yields are mainly based on the "green manure" from mangroves. The organic enrichment of ponds is usually from plant materials (especially from mangrove debris) (Fitzgerald, 2000). The amount of debris has to undergo a decomposition process before it becomes usable within the food chain of the cultured species. Results of the present study showed that there was a strong correlation between the MPCR and shrimp yields $(r>0.71, P<0.05)$, similar to a previous study (Baumgartner et al., 2016) where there was a strong correlation between the actual mangrove coverage 


\begin{tabular}{|c|c|c|c|}
\hline Location & Yields & Main cultured species & References \\
\hline $\begin{array}{l}\text { Tam Giang commune, } \\
\text { Nam Can District, Ca Mau } \\
\text { Province, Vietnam }\end{array}$ & $\begin{array}{l}76.62- \\
249.09\end{array}$ & $\begin{array}{l}\text { Penaeus monodon Fabricius, } 1798 \text { (main species), } \\
\text { Penaeus indicus Milne Edwards, 1837, Penaeus } \\
\text { merguiensis de Man, 1888, Metapenaeus ensis (De Haan, } \\
\text { 1844), and Metapenaeus Iysianassa (de Man, 1888) }\end{array}$ & Present study \\
\hline Tanggerang, Indonesia & 200 & $\begin{array}{l}\text { Penaeus monodon Fabricius, 1798, Penaeus merguiensis } \\
\text { de Man, 1888, Metapenaeus sp. Wood-Mason, } 1891\end{array}$ & Fitzgerald (2000) \\
\hline $\begin{array}{l}\text { Ujung Karawang, } \\
\text { Indonesia }\end{array}$ & 200 & $\begin{array}{l}\text { Penaeus monodon Fabricius, 1798, Penaeus merguiensis } \\
\text { de Man, 1888, Metapenaeus sp. Wood-Mason, } 1891\end{array}$ & \\
\hline Cikiong, Indonesia & 250 & Metapenaeus ensis (De Haan, 1844)(main species) & \\
\hline Pamanukan, Indonesia & 300 & $\begin{array}{l}\text { Penaeus monodon Fabricius, 1798, Penaeus merguiensis } \\
\text { de Man, 1888, Metapenaeus sp. Wood-Mason, } 1891\end{array}$ & \\
\hline Indramayu, Indonesia & 300 & $\begin{array}{l}\text { Penaeus monodon Fabricius, 1798, Penaeus merguiensis } \\
\text { de Man, 1888, Metapenaeus sp. Wood-Mason, } 1891\end{array}$ & \\
\hline Purwakarta, Indonesia & $228-273$ & Not available & Bosma et al. (2014) \\
\hline $\begin{array}{l}\text { Enterprises } 184 \text { Nam Can } \\
\text { District, Ca Mau } \\
\text { Province, Vietnam } \\
\text { Enterprises Tam Giang } \\
\text { III, Nam Can District, Ca } \\
\text { Mau Province, Vietnam }\end{array}$ & $204 \pm 54$ & $\begin{array}{l}\text { Metapenaeus ensis (De Haan, 1844)(main species), } \\
\text { Metapenaeus lysianassa (de Man, 1888), Penaeus indicus } \\
\text { Milne Edwards, 1837, Metapenaeus spinulatus Kubu, } \\
\text { 1949, Metapenaeus brevicornis (Milne Edwards, 1837), } \\
\text { Macrobrachium equidens (Dana, 1852), Penaeus } \\
\text { styliferus Milne Edwards, } 1837\end{array}$ & Johnston et al. (2000) \\
\hline $\begin{array}{l}\text { Ngoc Hien and Nam Can } \\
\text { Districts, Ca Mau } \\
\text { Province, Vietnam }\end{array}$ & 218 & Penaeus monodon Fabricius, 1798 (main species) & Ha et al. (2012) \\
\hline $\begin{array}{l}\text { Ngoc Hien District, Ca } \\
\text { Mau Province, Vietnam }\end{array}$ & 69-686 & $\begin{array}{l}\text { Penaeus indicus Milne Edwards, 1837, Penaeus } \\
\text { merguiensis de Man, 1888, Penaeus monodon Fabricius, } \\
\text { 1798, Metapenaeus ensis (De Haan, 1844) }\end{array}$ & Binh et al. (1997) \\
\hline $\begin{array}{l}\text { Ben Tre Province, } \\
\text { Vietnam }\end{array}$ & $204-324$ & Not available & Bosma et al. (2014) \\
\hline
\end{tabular}

and total income (derived from shrimp yields). Suryaperdana (2011) observed that the total shrimp yield increased from $154 \mathrm{~kg} \cdot \mathrm{ha}^{-1}$ to $353 \mathrm{~kg} \cdot \mathrm{ha}^{-1}$ when the mangrove coverage increases from $20 \%$ to $70 \%$, and found that shrimp yields $\left(\mathrm{kg} \cdot \mathrm{ha}^{-1} \mathrm{year}^{-1}\right)=3.8^{*} \mathrm{MPCR}$ +23 .

Nevertheless, too high MPCR in the integrated mangrove-shrimp farming system may cause potential problems. Firstly, high MPCR increased the potential toxicities of tannins from mangrove trees. Secondly, reduced flushing of water in ponds can lead to the potential of high BOD and reduced oxygen levels. Thirdly, high MPCR reduced penetrations of sunlight to the ponds, thereby lowering productivities of phytoplankton and benthic algae (shrimp's natural feed) (Le, 2006; Bosma et al., 2014). The reduction in water temperature affected by shadows was greater when the MPCR was $55 \%$ or higher. The DO of pond water was low during the rainy season and dry season when the MPCR was greater than $65 \%$ and $45 \%$, respectively (Le, 2006).

The optimal MPCR with regards to shrimp yields in integrated mangrove-shrimp farming system have not been consistent in the literature. However, most studies have shown that a MPCR between 30 and $50 \%$ is sufficiently good for the purpose (Le, 2006; Tran et al. 2013; Bosma et al. 2014). In this study, it can be concluded that a MPCR from $48.98 \%$ or greater can significantly increase shrimp yields. This was because ponds with MPCR from 48.98 to $72.50 \%$ showed significantly higher shrimp yields than the one with a MPCR of $42 \%$ (Fig. 3).

The Vietnamese government plans to expand organic certification to all integrated shrimp-mangrove farming systems along the entire coast of $\mathrm{Ca}$ Mau Province. According to Naturland (2014), the current organic farming standards demand an MPCR of $50 \%$. From the present study and others, it is fair to conclude that a MPCR of at least $50 \%$ would be ideal for the integrated mangrove-shrimp farming system in Vietnam.

Although the present study has shown significant results, future studies should also focus on the species composition and density of mangroves in order to maximise shrimp yields. Furthermore, a comparison of yields among different integrated farming systems (mixed, i.e. shrimps are raised in the long channels interleaved with bands of mangroves as in this study, and separate, i.e. shrimps and mangroves are raised in separate parts of the farms) 


\section{Conclusion}

Despite the low stocking density and no feeding, the total shrimp yields of the integrated mangrove-shrimp farming system in Ca Mau Province, Vietnamese Mekong Delta were generally high. The total shrimp yield per year ranged from 76.62 to 249.09 (including 37.93 to 108.64 for the black tiger shrimp (Penaeus monodon Fabricius, 1798), and 38.69 to 140.45 for other shrimps, namely Penaeus indicus Milne Edwards, 1837, Penaeus merguiensis de Man, 1888, Metapenaeus ensis (De Haan, 1844), and Metapenaeus lysianassa (de Man, 1888)). The mangrove to pond cover ratios ranged from 42.00 to $72.50 \%$. The relationships between the shrimp yields and mangrove-to-pond cover ratios would be more accurate if data were collected for a more extended period of 2-3 years or from a more significant number of shrimp ponds. The farmer's income from shrimp yields is usually seen as the primary benefit; however, the integrated mangrove-shrimp farming system is a sustainable practice to help conserve the mangrove forest, providing significant long-term benefits to the aquaculture industry.

\section{Acknowledgements}

This research is funded by Vietnam Academy of Science and Technology (VAST) under grant number VAST.CTG.06/14-16.

Conflict of interest: The authors declare that they have no conflict of interest.

\section{References}

Ahmed, N., Thompson, S., Glaser, M. 2018. Integrated mangrove-shrimp cultivation: Potential for blue carbon sequestration. Ambio 47:441452. https://doi.org/10.1007/s13280-017-0946-2

Badola, R., Hussain, S.A. 2005. Valuing ecosystem functions: an empirical study on the storm protection function of Bhitarkanika mangrove ecosystem, India. Environmental Conservation 32:85-92. https://doi.org/10.1017/S0376892905001967

Baumgartner, U., Kell, S., Nguyen, T.H. 2016. Arbitrary mangrove-towater ratios imposed on shrimp farmers in Vietnam contradict with the aims of sustainable forest management. SpringerPlus 5:438447. https://doi.org/10.1186/s40064-016-2070-3

Binh, C.T., Phillips, M.J., Demaine, H. 1997. Integrated shrimp-mangrove farming systems in the Mekong delta of Vietnam. Aquaculture Research 28:599-610. https://doi.org/10.1046/j.13652109.1997.00901.x

Bosma, R.H., Nguyen, T.H., Siahainenia, A.J., Tran, H.T., Tran, H.N. 2014. Shrimp-based livelihoods in mangrove silvo-aquaculture farming systems. Reviews in Aquaculture 8:43-60. https://doi.org/10.1111/raq.12072

Ca Mau Province Portal (CMPP). 2013. http://www.camau.gov.vn (Accessed 11 December 2019).

El-Regal, M.A.A., Ibrahim, N.K. 2014. Role of mangroves as a nursery ground for juvenile reef fishes in the southern Egyptian Red Sea. The

\section{https://doi.org/10.1016/j.ejar.2014.01.001}

FAO. 2007. The world's mangroves 1980-2005. Food and Agriculture Organization of the United Nations, Rome. 89 pp.

Fitzgerald, W.J. 2000. Integrated mangrove forest and aquaculture systems in Indonesia. In Proceedings of the workshop on mangrovefriendly aquaculture. (eds. Primavera, J.H., Garcia, L.M.B., Castaños, M.T., Surtida, M.B.), pp. 21-34. Iloilo City, Philippines.

Giri, C., Long, J., Abbas, S., Murali, R.M., Oamer, F.M., Pengra, B., Thau, D. 2015. Distribution and dynamics of mangrove forests of South Asia. Journal of Environmental Management 148:101-111. https://doi.org/10.1016/j.jenvman.2014.01.020

Giri, C., Ochieng, E., Tieszen, L.L., Zhu, Z., Singh, A., Loveland, T., Masek, J., Duke, N. 2011. Status and distribution of mangrove forests of the world using earth observation satellite data. Global Ecology and Biogeography 20:154-159. https://doi.org/10.1111/j.14668238.2010.00584.x

Ha, T.T.T., van Dijk, H., Bush, S.R. 2012. Mangrove conservation or shrimp farmer's livelihood? The devolution of forest management and benefit sharing in the Mekong Delta, Vietnam. Ocean \& Coastal Management 69:185-193. https://doi.org/10.1016/j.ocecoaman .2012 .07 .034

Hamilton, S. 2013. Assessing the role of commercial aquaculture in displacing mangrove forest. Bulletin of Marine Science 89:585-601. https://doi.org/10.5343/bms.2012.1069

Hutchison, J., Spalding, M., Ermgassen, P. 2014. The role of mangroves in fisheries enhancement. The Nature Conservancy and Wetlands International, the Netherlands. $54 \mathrm{pp}$.

Johnston, D., Van Trong, N., Van Tien, D., Xuan, T.T. 2000. Shrimp yields and harvest characteristics of mixed shrimp-mangrove forestry farms in southern Vietnam: factors affecting production. Aquaculture 188:263-284. https://doi.org/10.1016/S0044$\underline{8486(00) 00348-3}$

Jonell, M., Henriksson, P.J.G. 2015. Mangrove-shrimp farms in VietnamCoMPCRing organic and conventional systems using life cycle assessment. Aquaculture 447:66-75. https://doi.org/10.1016 /j.aquaculture.2014.11.001

Kusmana, C. 2018. Mangrove plant utilization by local coastal community in Indonesia. IOP Conference Series: Earth and Environmental Science 196:1-10. https://doi.org/10.1088/17551315/196/1/012028

Lan, N.T.P. 2013. Social and ecological challenges of market-oriented shrimp farming in Vietnam. SpringerPlus 2:675-684. https://doi.org/10.1186/2193-1801-2-675

Le, B.T. 2006. The relationship between mangrove and the environment, and its effects on shrimp and mangrove productivity in the integrated shrimp-mangrove system in Ngoc Hien districts, $\mathrm{Ca}$ Mau province. In: The role of mangrove and coral reefs ecosystems in natural disaster mitigation and coastal life improvement, Hong P.N. (Eds.), IUCN, MERD, Hanoi, Viet Nam, pp. 145-155.

López-Angarita, J., Roberts, C.M., Tilley, A., Hawkins, J.P., Cooke, R.G. 2016. Mangroves and people: Lessons from a history of use and abuse in four Latin American countries. Forest Ecology and Management 368:151-162. https://doi.org/10.1016/j.foreco $\underline{.2016 .03 .020}$

Murdiyarso, D., Purbopuspito, J., Kauffman, J.B., Warren, M.W., Sasmito, S.D., Donato, D.C., Manuri, S., Krisnawati, H., Taberima, S. Kurnianto S. 2015. The potential of Indonesian mangrove forests for global climate change mitigation. Nature Climate Change 5:10891092. https://doi.org/10.1038/nclimate2734 
Naturland 2014. http://www.naturland.de/images/UK/Naturland /Naturland_Standards/Standards_Producers/NaturlandStandards_Aquaculture.pdf (Accessed 13 September 2019).

Olson, K.R., Morton, L.W. 2018. Polders, dikes, canals, rice, and aquaculture in the Mekong Delta. Journal of Soil and Water Conservation 73:83A-89A. https://doi.org/10.2489/jswc.73.4.83A

Richards, D.R., Friess D.A. 2016. Rates and drivers of mangrove deforestation in Southeast Asia, 2000-2012. Proceedings of the National Academy of Sciences 113:344-349. https://doi.org/10.1073/pnas.1510272113

Sandilyan, S., Kathiresan, K. 2015. Mangroves as bioshield: an undisputable fact. Ocean \& Coastal Management 103:94-96. https://doi.org/10.1016/j.ocecoaman.2014.11.011

Spalding, M., Kainuma, M., Collins, L. 2010. World atlas of mangroves. Earthscan, London/Washington DC. $319 \mathrm{pp}$.

Suryaperdana, Y. 2011. The relationship of mangrove environment against shrimps and milkfish production in silvofishery areas Blanakan, Subang, West Java. MSc Thesis. Institute of Fisheries
Bogor, Indonesia. 55 pp. (in Indonesian).

Takashima, F. 2000. Silvofishery: An aquaculture system harmonized with the environment. In Proceedings of the workshop on mangrovefriendly aquaculture. (eds. Primavera, J.H., Garcia, L.M.B., Castaños, MT., Surtida, M.B.), pp. 13-19, Iloilo City, Philippines.

Tran, T.P.H., van Dijk, H., Bosma, R.H., Le, X.S. 2013. Livelihood Capabilities and Pathways of Shrimp' Farmers in the Mekong Delta Vietnam. Aquaculture Economics \& Management 17:1-30. https://doi.org/10.1080/13657305.2013.747224

Valiela, I., Bowen, J.L., York, J.K. 2001. Mangrove forests: one of the World's threatened major tropical environments. Bioscience 51:807815. https://doi.org/10.1641/00063568(2001)051[0807:MF00TW]2.0.C0;2

Walters, B.B., Rönnbäck P., Kovacs, J.M., Crona, B., Hussain, S.A., Badola, R., Primaverae, J.H., Barbier, E., Dahdouh-Guebas, F. 2008. Ethnobiology, socio-economics and management of mangrove forests: A review. Aquatic Botany 89:220-236. https://doi.org $\underline{\text { /10.1016/j.aquabot.2008.02.009 }}$ 